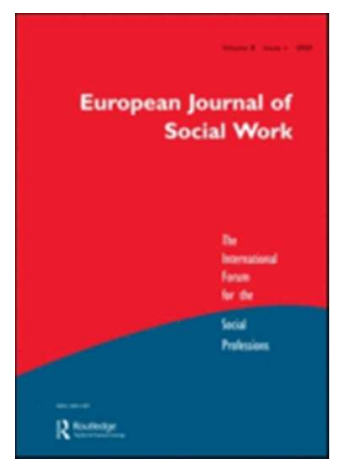

\title{
E-SOCIAL WORK IN EUROPE: AN EMPIRICAL ANALYSIS OF THE PROFESSIONAL BLOGOSFERE IN SPAIN, PORTUGAL, FRANCE AND ITALY
}

\begin{tabular}{|r|l|}
\hline Journal: & The European Journal of Social Work \\
\hline Manuscript ID & Draft \\
\hline Manuscript Type: & Original Article \\
\hline Keywords: & $\begin{array}{l}\text { E-Social Work, Blog, Blogosfere, Virtual Community, Professional } \\
\text { Cyberculture }\end{array}$ \\
\hline \multicolumn{2}{|l}{} \\
\hline
\end{tabular}

SCHOLARONE ${ }^{m}$

Manuscripts 


\section{E-SOCIAL WORK IN EUROPE: AN EMPIRICAL ANALYSIS OF THE PROFESSIONAL BLOGOSFERE IN SPAIN, PORTUGAL, FRANCE AND ITALY}

\section{Introduction}

Currently, people live in a digital society determined by the information technology paradigm (Castells, 2009). In a very short time, as a consequence of the new information and communication technologies (ICTs), the means of learning, interprofessional relations and interactions between professionals and users in all spheres of human relations have been modified.

In the last decades, information and communication technologies (ICT) have penetrated all fields of social reality, giving rise to a new era (the information age) and a new social structure (and morphology) that can be properly referred to as 'network society' (Castells, 2009). The widespread use of digital communication technologies in Web 2.0 (social networks, wikis and blogs) have made it possible for new forms of socialisation in general, and professional socialisation in particular to emerge, to which social work is not a stranger. In this ubiquitous and ever changing context, it is necessary to investigate various dimensions of E-Social Work, which is one of the emerging professional and disciplinary challenges in the 21st century (López Peláez and Díaz, 2015).

In this 'internet galaxy' (Castells, 2001) tools of various kinds that enhance the interaction between all people, both personally and professionally, have proliferated. This is the case of blogs, which, although they started as private instruments, nowadays they address the occupational field, constituting a novel and interesting fact which has been investigated in the last few years in fields such as politics, education, or journalism (Cabero et al., 2009; Aguaded and López, 2009; Casas, 2010; Aznar and Soto, 2010; Remondino, 2012, Colussi, 
2013; García-Martín and García-Sánchez, 2015) but which has not yet been analysed in the Social Work area.

\section{Blogs as an object of social research}

While the virtual world as a 'culture of simulacrum' was already present in Baudrillard's (1983) work, publications about internet and other forms of computer-mediated communication in cyberspace emerge in the second half of the 1990s (Featherstone and Burrows 1995, Turkle 1995, Rheingold 2000, Silver 2000). At the same time, new forms of social research in cyberspace were explored and new data collection tools were proposed (Coomber, 1997, Hewson et al., 2003, Mann and Stewart, 2000). At that time, some papers (Hine, 2005; Jhons et al., 2004; Jones, 1999; Coombes, 2001) had already shown that cyberspace offered a new and exciting frontier for social research.

The weblog is a tool which expanded from 1999 (Hookway 2008), and is considered by social scientists as one of the richest sources of qualitative data for being an online self-presentation tool that provides chronologically sorted information and constitutes an expression of 'common knowledge' (Serfarty, 2004, Bar-Ilan, 2005). The ease of access, the public availability of its contents on a global scale, the immediacy and the low cost in the data collection, as well as its naturalistic character in text format (which avoids the expensive recording and transcription work in another type of qualitative data collection), together with the possibility of reaching geographically or socially distant populations by the researcher (Hessler et al., 2003; Mann and Stewart, 2000), make blogs an object of study and social research of great interest. Nevertheless, research in the 'blogosphere' implies ethical aspects such as the authenticity of data and contents, or the privacy/anonymity of authorship, as well as the recruitment of participants that must be taken into account (Hookway, 2008). 
Although blogs can be considered logs or journals of life, they present notable differences with the traditional diaries and personal documents that historically have been used in social research (in the field of history and anthropology basically, although in sociology there are also classic works such as that of WI Thomas and F. Znaniecki (1918-1920) The polish peasant in Europe and America, based on the analysis of letters). The difference between blogs and journals and other personal documents (mainly letters) that have been used in social research as data sources for a century, is that blogs are written for an implicit audience, when not openly explicit (Hookway, 2008). Therefore, the ways to approach the treatment of these texts, cannot be the same as when analysing private or personal letters or diaries. In fact, the blog is already considered a new genre (Miller and Shepherd, 2004; Gurak et al., 2004), which also allows a certain co-production between authors and readers.

According to the display device blogs can be, among others: Openblog, Fotolog, Videoblog, Audioblog, Moblog, Tumbleblog, or Microblog. Depending on the privacy settings, blogs can be of three types: private, just for friends, or public. This third type of blog is what constitutes our object of study. The aspects related to the anonymity allowed by the cyberspace have been treated extensively in the scientific literature (Holenbaugh and Everett, 2008, Frye and Dornich, 2010), but are not relevant in our study, given that for the selection of blogs the established inclusion criteria is the identification of their authorship and the possibility of communicating with the author of the blog by e-mail. However, one of the challenges which the social blog research presents is the 'unmanageable multiplication of voices' that it entails and that makes the researcher face a real 'black hole', which is one of the most serious challenges of the blogosphere (Hookway, 2008, p.8). Jameson (1991) described the disorientation and anxiety provoked by postmodern spaces and, confronting the blogosphere as a field of study, is undoubtedly one of those spaces generating anxiety and disorientation. 


\section{The blogosphere and the blog culture}

The blogosphere is the communication sub-space generated in the network through blogs. The blog, as a format or evolutionary stage of the Web, is still a relatively important step towards the construction of a new 'textuality', multimodal (the text transcends as a format in its path towards the visual and the multimedia) and fragmentary (in the content, but also in the processes of creation or distribution), typical of a new generation of digital natives who need not be aware of its existence (Fumero and Sáez-Vacas, 2006, p.68).

The key principles which define cyber culture, according to Lévy (1997), are interconnectivity, virtual communities and collective intelligence. These principles provoke a new order of knowledge and individual and collective experience, a cultural model that articulates as the third stage on an evolutionary scale ranging from small closed societies - oral culture - to those civilized or imperial - where writing has a significant role - up to reaching cyber culture, which corresponds to a stage of specific globalisation of societies, of coexistence between the local and global levels (Ardèvol, 2003, p.7).

The relations of info technology with activities in the infocity alter the usual social networks, to form new types of networks, as is the case of blogs. The blogosphere is another structure of information (Saez-Vacas, 2005). An emerging culture based on sharing, including blogs, wikis, open sources, etc. With this, millions of people who were formerly mere receivers have become very active participants, as well as co-authors or co-producers in different social networks.

Since Rheingold (1993) coined the term 'virtual community', several researches have been made trying to explain the dynamics and relationships existing in the different types of 
communities. Blogs are not an exception and are shaped as catalysts for the emergence of a new type of community, with a social dynamic of the new technological environment (Blanchard, 2004; Fumero and Saez-Vacas, 2006: 71). White (2006) distinguishes three types of virtual communities: Single Centric Community Blog/Blogger (they appeared first and are populated with commentators who could eventually decide to edit their own blog); Central Connecting Topic Community (a natural extension of the CoP - Communities of Practices - or communities of interest that encounter the explosion of the blog in a sociotechnical context different from the traditional one), and Boundaried Commnunity (isolated community).

\section{E-Social Work}

As a result of the increasing addition of New Management approach to the sphere of social services (Steyaert and Gould, 1999; Langan, 2000; Jordan and Jordan, 2000), the professional practice and provision of welfare services relationships, have been affected by information and communication technologies (Humphries and Camilleri, 2002, Harlow, 2003, Webb, 2003, Garrett, 2005, Rafferty and Steyaert, 2007, Harris and White, 2009 and Coleman, 2011), in ways not without controversy (Sapey, 1997; Garret, 2005; Dustin, 2008; Ferguson, 2008; Harris and White, 2009), giving rise to new characterisations of social work such as 'Liquid Social Work' (Ferguson, 2008) or 'The McDonaldization of Social Work' (Dustin, 2008). In any case, a new approach or perspective of social work called E-Social Work is emerging, of which the virtual community thematic of social work bloggers, constitutes one of its de facto manifestations.

Coleman (2011) established an exhaustive characterisation of E-Social Work, based on the systematic observation of the social work developed in 'Contact Centres', however, the 
definition proposed by Lopez Peláez and Díaz (2015), seems more timely and adjusted to the diversity of the professional intervention:

E-Social Work is a specialized sphere of social work that aims to analyze, assess and intervene in the on-line environment by developing strategies to reach out to users, assess their needs, and design the appropriate dynamics to intervene and empower them in the online context. The ultimate aim is to provide assistance to a population that is defined as digital natives, in both online and offline environments' (...) 'E-Social Work can be defined as the use of new information and communication technologies in the field of social work and social services. ESocial Work includes online research, patient treatment (individual therapy, group and community dynamics), the training and teaching of social workers, and the monitoring of social service programs (López Peláez and Díaz, 2015, p. 44).

In this sense, the thematic community of social work bloggers constitutes in itself a relevant and susceptible element of systematic investigation of E-Social Work.

\section{Methodology}

The research process has been developed in four phases:

- Exhaustive bibliographic review which supports and structures the theoretical framework, the discussion of results and selection of procedures and data collection techniques.

- Search and systematic identification of social work weblogs in Spain, France, Portugal and Italy, throughout online search engines and expert consultation. 
- The selected blogs (from February $10^{\text {th }}$ to March $1^{\text {st }}, 2017$ ) have been analysed through three international instruments measuring quality and global relevance: Google PageRank ${ }^{1}$, Rankin Alexa ${ }^{2}$ and Majestic ${ }^{3}$.

- In view of the risks and obvious limitations of the available global metric tools, an online survey (from February $22^{\text {nd }}$ to March 3rd, 2017) was conducted, aiming all social work blogs identified with authorship and e-mail address.

Sample: The youth of the weblogs and their dynamism goes beyond any representative sample delimitation, therefore, the search for specialized weblogs has followed two parallel procedures. The first one consisted of the use of keywords in Google: 'social work', 'social service', 'social assistant', 'social worker' and 'assistant of social service' (in the four official languages of the countries object of this study). The second has focused on direct contacts with other bloggers through the Spanish BlogoTSfera (private Facebook group and WhatsApp instant messaging group) and Facebook groups (public and private, with 15,000 members) dedicated to social work and social work blogs (12,207 members), from which other international contacts were chained.

To the obtained list (153 blogs of the four countries), the following criteria were applied as general criteria of inclusion: authorship of social work; being blog or weblog; addressing issues related to Social Work; inclusion of the author's own contributions on Social Work; and addressing useful topics for basic or specialized training in Social Work.

After this first screening of weblogs, a second one was carried out applying the criteria established by BlogoTSfera (Arredondo, 2016): that the author is a social worker or practicing profession; the authorship of the blog being identified; minimum age of the blog being three months; regularity in the publication of articles; being free of invasive advertising; and

\footnotetext{
${ }^{1}$ https://www.pagerank.net/pagerank-checker/

${ }^{2} \mathrm{https}: / /$ alexa.com

${ }^{3}$ https://majestic.com/
} 
respecting the professional code of ethics. As a final result of these selection processes a list of 50 weblogs was obtained.

Analysis: The international metric tools Ranking Alexa, Majestic and Google PageRank have been applied. The significant absence of social work weblogs in Google PageRank has allowed us to use only Ranking Alexa and Majestic. There have been 24 weblogs finally selected (6 per country). The sample has been comparatively analysed in Ranking Alexa and Majestic. The latter provides information about the trust of a page (Trust Flow), the quantity (Backlinks) and quality of links (Citation Flow). Although Majestic shares with Alexa the measurement of the number of links and keywords, their results do not always concur.

For this reason, an online survey has been included as a complementary research technique to evaluate, in a proper measure, the situation of weblogs within the e-social work area. It has been distributed through Google Form in Spanish and English to the 50 bloggers who made up the sample prior to the final selection. Twenty-three questionnaires were received between February $22^{\text {nd }}$ and March $3^{\text {rd }}, 2017$, with a response rate slightly lower than $50 \%$. The statistical analysis, performed with SPSS, was descriptive given the small sample size.

\section{What do global metrics tell us about the professional blogosphere in Southern Europe?}

Once the international standard analytical tools Ranking Alexa and Majestic have been applied, it is possible to establish the scope of social work blogs, on the set of all Internet Sites.

A first comparative result which has been verified from traffic data (visits and visitors), is the Reputation of the blog: this data (Sites Links) refers to the number of links the blogsite receives. For this ranking there is no pre-established standard score range, but allows to compare and prioritise a set of blogs, as shown in Table 1. 
Out of the 12 best blogs scored in this ranking (with values between 37 and 12), half (6) are Spanish, 3 are Italian and 2 are Portuguese. If we consider the four blogs that scored over 30 points, we find 2 from Spain, 1 from Portugal and 1 from Italy. According to this first global standard valuation indicator, it could be established as the first provisional result that the countries with the best reputation for their blogs in social work are, in this order: Spain, Portugal, Italy and France.

The Alexa analytical tool also allows you to evaluate the scope of blogs in the global context. Unlike Reputation, in Global Rank the lower the figure, the better overall positioning the blog ${ }^{4}$ has. That is, the higher the number, the worse positioned a blog is on the Global Internet.

In the first place, it is noted that none of social work blogs is amongst the blogs with the largest global range. An expected fact, given that blog search engines do not include the 'Social Work' category / tag, and none of the ranking categories or tags for blogs in global search engines ${ }^{5}$ include similar topics.

However, the fact that 5 social-themed blogs with a value below 2,000,000 (2 from Italy, 1 from Portugal and 2 from Spain) appear in Alexa's Global Rank, would indicate that 'we are in the right track', according to the creators of Alexa. In a comparative perspective by countries, according to Global Rank, the blogs with the best global reach are those from Italy (2), Portugal (1) and Spain (2).

\footnotetext{
${ }^{4}$ Less than 100.000 is the best result; less tan 500.000 is the very good result; and less than 1.000 .000 is not bad result.

${ }^{5}$ The most frequent categories/menus of blog search engines are: technology, hobbies, shows, health, science, education, NGO, government, marketing, software, human resources, business, motor, etc. As social work blogs can be included in several of them, it is really difficult to find Social Work themed blogs with any of these tools.
} 
The difference in results - by blogs and by country ${ }^{6}$ - between these two global Alexa indicators, shows that such global metrics are not risk free, therefore, should not be taken as definitive indicators. To address these limitations, it is advisable to use several global metric tools, which allow us to adjust and contrast the results so that the analysis can be better refined.

Considering the complementarity with Alexa, we have also analysed the scope of social work blogs with Majestic. The most useful scope and positioning indicators for social work offered by Majestic are the Citation Flow (an indicator from 0 to 100 used to measure the equivalence of links or "power" which the website or the link carries), combined with the Trust Flow (a quality indicator on a scale from 0 to 100) which is Majestic's trademark. Another useful indicator is the Backlink (incoming link coming from a website or web domain other than the analysed blog). The results obtained, compared by country, with these three Majestic indicators, are shown in Table 3.

The Trust Flow and Citation data allow to generate a comparative ranking among blogs and among countries. However, we observed that the list does not match, so it will be necessary to be cautious with this type of metrics, whose result varies according to the type of indicator used. If we pay attention to the relative importance of the two indicators established by Majestic, its brand indicator is the Trust Flow. However, in light of the results, it cannot be said that Trust Flow is a more powerful or credible indicator than Citation. These two indicators use data on the number of links (power) which the site has internally. But if we consider the number of external links (outside the blog itself) that lead to the blogsite (which could be considered external impact of the blog from the number of sites that link it from

\footnotetext{
${ }^{6}$ As we can see by comparing Reputation and Global Rank, the blog listings that emerge best positioned according to these variables, are not identical.
} 
outside the blog itself) then the Backlinks indicator would be the most appropriate to measure the external impact of the blog in question.

Having in mind that both Alex and Majestic offer metrics of external impact (measured in both cases by the number of external links which lead to a specific blog), it might be interested to compare both results (table 4):

In spite of considering the same type of data (external links which lead to a blog), neither the blogs nor the listings by country match. Moreover: they vary a great deal from one to another. This analysis advises not taking any of these metrics as final indicators, much less using it to establish possible quality levels among blogs and among countries. We make this statement, as we have to have in mind (as mentioned in the methodology section) that Majestic indicators have been obtained only for blogs previously evaluated with Alexa, since we expected to check the level of coincidence between both global tools. In this respect we can state, in view of the results, that there is no consistency between Alexa and Majestic, nor among Alexa's or Majestic's own indicators.

In order to strengthen the analysis of these results, another consistent measuring exercise has been carried out, consisting of applying Majestic's indicators without conditioning them to the previous filter of the list of Alexa blogs. That is, Majestic indicators have been used on the 50 blogs initially identified in the four countries (without the criteria of a fixed and reduced number of blogs per country). The results are shown in table 5.

Finally, if we compare the Alexa and Majestic rankings for the 24 best positioned blogs in both tools, the result is as follows:

In view of the results obtained, we question the goodness and/or relevance of the metrics we borrowed from traditional media (generally created in the field of online marketing) and which, in general, are still used to quantify the impact of a set of tools and communication 
spaces which - supported in its supposedly conversational dynamics - transcend the concept of 'audience' (Fumero and Sáez-Vacas, 2006: 72). For that reason, we have expanded our study on E-Social Work in the professional blogosphere, conducting a fast online survey, aimed at the 45 bloggers who had an e-mail contact on their blog, from the four countries.

\section{What is inside the professional blogosphere of social work?}

The 23 bloggers who answered the survey (conducted between February $22^{\text {nd }}$ and March $3^{\text {rd }}$, 2017), do not exactly match the list of blogs analysed with Alexa and Majestic, nor do they have a homogenous distribution by country (19 respondents from Spain, 3 from Portugal and 1 from Italy), which is why we will examine the results of this survey separately from those of global positioning on the Internet. This quick poll has been carried out to provide us with non-public information and data, but which can be very useful to establish the blogger profile in social work; to know whether or not there is a possible virtual thematic community in social work; whether blogs can be a space for online professional socialisation; and other aspects that cannot be observed with global metric tools (such as Alexa or Majestic); nor analysing the public view of blogs.

Considering that the first blog on the Internet dates back to 1996, and that the worldwide bloom of blogs occurred from 1999 (Hookway, 2008), the professional blogosphere is relatively young; since less than $9 \%$ of social work blogs were created before 2010 , and more than one third are less than three years old. These data show that the incorporation blogs as professional tools in the field of e-social work is very recent (almost 90 percent of blogs are less than 10 years old). We could therefore say, that the blogosphere of social work is a 'baby' compared to the global blogosphere, which would be a 21 year old 'young adult'.

Regarding the blogger profile in social work, they all are university graduates in social 
work; from which more than a quarter (25.9\%) have, in addition, another university degree on of social sciences (sociology and political science, law or philosophy). Nearly a third have postgraduate studies at a master level, and almost $9 \%$ of bloggers also hold a doctorate degree. These data show a higher and more skilled level of bloggers than the average academic level of all professionals in the four countries. A great majority (78.3\%) perform only one type of professional activity (whether in the public, private or third sector), but more than one fifth $(21.7 \%)$ perform two or more types of professional activities: either combining the free exercise of their profession or consulting work, with teaching and research; or professional practice in the public or private sector with teaching and research, or consultancy. The social worker blogger profile also stands out for its social commitment, since more than half $(52.2 \%)$ do some kind of volunteering, apart from their professional practice and paid employment. This voluntary service is, in most cases, social activism committed to the defence of human rights, feminism or social transformation. With this profile, it is not surprising that the target audience (audience) of the professional blogosphere are both social workers, professionals from other disciplines and fields of social intervention, as well as students and public in general. That is, the interest and influence of the blogosphere goes beyond the professional space, until in some cases it reaches society as a whole.

The size of the audience of professional blogs varies greatly depending on whether it is a personal blog or an institutional blog. Almost half of blogs have less than 1000 followers (35\% have less than 100) and only $13 \%$ have more than 10,000 followers. In these 3 blogs with more than 10,000 followers, two of them are actually institutional weblogs and only one of them is a personal blog. The size of the audience is quite low, except for those exceptions, when compared to blogs from other fields such as education or health. Having said that, as far as blog connectivity with social networks is concerned, all bloggers have linked their blog 
with at least one social network (either Facebook, Twitter or LinkedIn), and more than $80 \%$ have it linked to two or more social networks. The networks preferred by social work bloggers are, in this order: Facebook (38\%), Twitter (34\%) and LinkedIn (22\%).

Social work bloggers have a very variable posting frequency, although almost $90 \%$ published less than 50 posts in 2016. In terms of visits, more than one-fifth received less than 100 total visits in 2016 and 40\% received between 10,000 and 100,000 visits that same year. If we take into account the number of visitors (data which is unknown to more than half of bloggers) a fifth has between 10,000 and 100,000 visitors a year, compared to $15 \%$ with less than 5,000. That is to say, there are two types of professional blogs: blogs with little audience/visitors and blogs with a very wide audience, not seeming to be balanced. With regards to the geographical origin of the visitors, $32.7 \%$ come from Spain; 27\% from Latin America; $15 \%$ from North America; 13\% from Europe; 8\% from the whole world; And 2\% from Africa.

The interesting fact is to note that neither the age of the blog, nor the number of followers, visits or visitors, is related to the interactivity-feedback between the author and the audience. The interactivity between author and reader is important to determine if the blogosphere in social work is a space of professional socialisation or not. In this sense, although most blogs embrace the possibility of the reader to contact privately with the author, the truth is that only $52 \%$ allows public comments to be written on the blog by the readers. Comments are scarce ( $78 \%$ receive an average of less than 4 comments per post), and are associated neither to the age of the blog nor to the number of posts published. That is, the author-reader interaction is defined more by the profile and style of the blog than by its age or number of publications. The same goes for the number of followers, visits and visitors: it does not depend on the age of the blog nor the number of posts published.

The topics in the professional blogosphere are, in this order, as follows: social work $(16.3 \%)$; social services (12.4\%); social policy (11.7\%); welfare state $(10.8 \%)$; defence of rights 
(9.3\%); ethics (8.5\%); gender (8.5\%); education (7\%); health (5.4\%); employment $(5.4 \%)$; and others (art, migration, entrepreneurship, computer applications, social communication, social theatre). The predominant original contents published are: theoretical and conceptual reflections (25\%); experiences and professional practice (25\%); topical issues (16\%); methods and techniques (14.3\%); reports and defence of rights (14.3\%); or others $(5.4 \%)$.

\section{Conclusions}

Finding blogs is undoubtedly the first step of any research within the blogosphere, but in the absence of the specific category 'Social Work' in web-based online services (blog classification categories are usually much broader, such as 'celebrities', 'leisure and entertainment', 'politics', 'health and welfare, 'education', 'technology', etc.), our challenge has not been fully solved with BCMS online tools (Blog Content Management Systems). We have resorted to procedures that have proven to be more reliable for the case of Spain than for the cases of France, Portugal and Italy (with a blogosphere officially recognised by the Spanish General Social Work Council); although in those three other countries we have crossreferenced several detection sources to have greater validity in the final selection.

The most reliable global analytics tools, such as Alexa and Majestic (Google PageRank does not yield results for identified social work blogs), have not proved valid for reliable comparisons by country or by author. These are useful tools to know certain aspects related to the impact, measured in terms of links that the blog receives, but the lack of coincidence in the obtained results advises to use these tools only with exploratory character and as a complement to other types of sources.

Having been our first empirical study of the social work blogosphere, we cannot contrast the results obtained with any other similar study in the field of e-social work. Nor are there 
studies like ours (comparative by country) in other nearby professional fields. The results obtained with the applications Alexa and Majestic, show that the best positioned blogs are usually institutional, which publish content, not always original (job offers, call announcements, links to press articles, newsletters, etc.).

Among personal blogs, it has not been possible to separate those that are strictly social work, from others that - written by social workers - are a much broader journalistic type of blog. In addition, the fact that in France, the term 'travail social' covers all social professions, in contrast to Spain or Portugal where the expression 'social work' only applies to a specific profession, forces us to be cautious with the lists obtained.

The online survey has proved to be a useful tool to know aspects of the professional blogosphere that would otherwise have remained hidden (since certain data cannot be obtained by browsing each blog). Nevertheless, given the small sample size that we have obtained for this study, it is convenient to take the presented results as a first preliminary approximation.

Taking into account that our survey has been answered by 19 Spanish bloggers, 3 Portuguese and 1 Italian; and considering that of the 3 Portuguese blogs, two are institutional (web and blog) and only one is personal; we need to deepen the study of the blogosphere using more restrictive exclusion criteria that allows us to compare institutional blogs on the one hand and personal blogs on the other. At least in quantitative aspects (number of followers or number of posts, for example), where the nature of the blogger is a determining factor of results. In this sense, we can anticipate that the professional blogosphere is, in all cases, an informational space. And in certain cases (only in the case of blogs where there is evidence of more interaction between author and reader) it can be said that apart from being an informational space, the blogosphere would also be a space for professional socialisation, although still under construction. 
On the other hand, the linguistic community is another relevant factor to consider in future studies of the blogosphere, since the language is a decisive geographic factor of the audiences. The existence of a Spanish Blogosphere, officially recognised and supported by the General Council of Social Work of Spain, where the bloggers' community holds face-to-face meetings at national social work conferences, joint publications (Arredondo, 2016), or launches global activities (such as the blogging festival in 2017 on the occasion of World Social Work Day), constitutes an experience of enormous interest that should be taken into account in other linguistic communities, as a practice which tends to construct a new space for professional socialisation within the framework of e-social work.

The social work blogosphere is very young compared to the educational or sanitary blogosphere, however it indicates a great dynamism and a great growth potential. This circumstance would advise to carry out more exhaustive studies by country or linguistic community. The selection of countries which we have studied, in view of the audiences received in the blogs, suggest that the Ibero-American community (where Spanish and Portuguese are spoken) has a better chance of constituting itself as a space of professional socialisation, compared to the French-speaking or Italian communities, for instance.

\section{References}

Ardévol, E. (2003). La cibercultura: un mapa de viaje [The cyberculture: a map of trip]. Aportaciones al Seminario Pensar la Cibercultura, Antropología y Filosofía del Nuevo Mundo. Retrieved from: http://www.eardevol.files.wordpress.com/2008/10/eardevol_cibercultura.pdf

Arredondo Quijada, R. (coord.) (2016). Trabajo Social ONLINE. Lo mejor de la blogoTSfera [Social Work ONLINE. The Best of BlogoTSfera]. Madrid: Consejo General del Trabajo Social. Retrieved from: https://www.cgtrabajosocial.es/publicaciones/trabajosocial-online-lomejor-de-la-blogotsfera/86/view

Bar-Ilan, J. (2005). Information Hub Blogs. Journal of Information Science, 31(4), 297-307. 
Retrieved from: http://journals.sagepub.com/doi/pdf/10.1177/0165551505054175

Baudrillard, J. (1983). Simulations. New York, NY: Semiotext(e).

Blanchard, A.L. (2004). Blogs as Virtual communities: Identifying a Sense of Community in the Julie/Julia Project. In L.J. Gurak, S. Antonijevic, L. Johnson, C. Ratliff and J. Reyman (eds) Into the Blogosphere: Rhetoric, Community, and Culture of Weblogs. Retrieved from: http://blog.lib.umn.edu/blogosphere/blogs_as_virtual.htm

Castells, M (2009). The Rise of the Network Society (2nd ed.). Hoboken, NJ: WileyBlackwell.

Coleman, N. (2011). E-Social Work: A preliminary Examination of Social Services Contact Centres. Thesis Degree PhD of Philosophy in Social Work, University of Warwick. Retrieved from: http://go.warwick.ac.uk/wrap/51364

Coombes, H. (2001). Research Using IT. Hampshire: Palgrave.

Coomber, R. (1997). Using the Internet for Survey Research. Sociological Research Online 2(2). Retrieved from: https://chnm.gmu.edu/digitalhistory/links/cached/chapter6/6_28b_survey.htm

Dustin, D. (2008). The McDonaldization of Social Work. Aldershot: Ashgate.

Featherstone, M. \& Burrows, R. (eds) (1995). Cyberspace, Cyberbodies, Cyberpunk: Cultures of Technological Embodiment. London: Sage.

Ferguson, H. (2008). Liquid Social Work: Welfare Interventions as Mobile Practices. British Journal of Social Work, 38(3), 561-579. doi: 10.1093/bjsw/bcl367

Frye, N. E. \& Dornisch, M. M. (2010). When is trust not enough? The role of perceived privacy of communication tools in comfort with self-disclosure. Computers in Human Behavior, 26, 1120-1127. doi:10.1016/j.chb.2010.03.016

Fumero, A. \& Saez-Vacas, F. (2006). Blogs: en la vanguardia de la nueva generación web [Blogs: In the Forefront of the New Web Generation]. Novática, 183, 68-73. Retrieved from: http://oa.upm.es/11148/

Garrett, P.M. (2005). Social Work's 'Electronic Turn': Notes on the Deployment of 59 
Information and Communication Technologies in Social Work with Children and Families. Critical Social Policy, 25(4), 529-553. doi: 10.1177/0261018305057044

Gurak, L., Antonijevic, S., Johnson, L., Ratliff, C. \& Reyman, J. (2004). Introduction: Weblogs, Rhetoric, Community, and Culture. University of Minnesota. Retrieved from: http://hdl.handle.net/11299/172840

Harlow, E. (2003). Information and Communication Technologies in the Welfare Services: Wired Wonderland or Hypertext Hell?. In E. Harlow and S. Webb. (eds) Information and Communication Technologies in the Welfare Services, London: Jessica Kingsley.

Harris, J. \& V. White (eds.) (2009). Moderninsing Social Work: Critical Considerations, Bristol: Policy Press.

Hessler, R., Downing, L., Beltz, C., Pelliccio, A., Powell, M. \& Vale, W. (2003). Qualitative Research on Adolescent Risk Using E-mail: A Methodological Assessment. Qualitative Sociology, 26(1), 111-24. doi:10.1023/A:1021460205328

Hewson, C., Yule, P., Laurent, D. \& Vogel, C. (2003). Internet Research Methods. London: Sage.

Hine, C. (2000). Virtual Ethnography. London: Sage.

Hollenbaugh, E. E. (2011). Motives for maintaining personal journal blogs. Cyberpsychology, Behavior, \& Social Networking, 14, 13-20. doi:10.1089/cyber.2009.0403

Hollenbaugh, E. E. \& Everett, M. K. (2013). The Effects of Anonymity on Self-Disclosure in Blogs: An Application of the Online Disinhibition Effect. Journal of Computer-mediated Communication, 18, 283-302. doi:10.1111/jcc4.12008

Humphries, P. \& Camilleri, P. (2002). Social Work and Technology: Challenges for Social Workers in Practice: A Case Study. Australian Social Work, 55(4), 251-259. doi: 10.1046/j.0312-407X.2002.00038.x

Johns, M., Chen, S.S \& Hall, G. (eds) (2004). Online Social Research: Methods, Issues and Ethics. New York, NY: Peter Lang.

Jones, S. (ed.) (1999). Doing Internet Research: Critical Issues and Methods for Examining 
the Net. London: Sage.

Jordan, B. \& Jordan, C. (2000). Social Work and the Third Way: Tough Love as Social Policy, London: Sage.

Langan, M. (2000). 'Social Services: Managing the Third Way', in J. Clarke, S. Gewirtz, and E.M. McLaughlin (eds) New Managerialism, New Welfare? London: Sage.

Lévy, P. (1997). La cibercultura, el segon diluvi? [The cyberculture. The second deluge?] Barcelona: Edicions UOC-Proa.

Lopez Pelaez, A. \& Diaz, H. L. (2015). Social work challenges in the 21 Century: Citizenship, Technology and E-Social Work. In A. Lopez Pelaez (Coord.) Social Work Challenges in the XXI Century: Perspectives from USA (pp. 29-53). Madrid: Thomson Reuters/Aranzadi.

Mann, C. \& Stewart, F. (2000). Internet Communication and Qualitative Research: A Handbook for Researching Online. London: Sage.

Miller, C.R. \& Shepherd, D. (2004). Blogging as Social Action: A Genre Analysis of the Weblog. University of Minnesota. Retrieved from: http://hdl.handle.net/11299/172818

Rafferty, J. \& Steyaert, J. (2007). Social Work in a Digital Society. In K. Postle and M. Lymbery (eds) Social Work: A Companion to Learning (pp. 165-176). London: Sage.

Rheingold, H. (2000). The Virtual Community: Homesteading on the Electronic Frontier (Revised Ed.). Cambridge, MA: MIT Press.

Saez Vacas, F. (2005). El poder tecnológico de los infociudadanos. Diarios y conversaciones en la Red Universal Digital [The technological power of the infocitizen. Diaries and conversations in the Universal Digital Network]. Telos, 65, 66-67. Retrieved from: https://telos.fundaciontelefonica.com/telos/articulocuaderno.asp@idarticulo=4\&rev=65.html

Sapey, B. (1997). Social Work Tomorrow: Towards a Critical Understanding of Technology in Social Work. British Journal of Social Work, 27(6), 803-14. doi:10.1093/oxfordjournals.bjsw.a011280

Silver, D. (2000). Looking Backwards, Looking Forward: Cyberculture Studies 1990-2000. In 
D. Gauntlett (ed.) Web.Studies: Rewiring Media Studies for the Digital Age (pp. 19-30). London: Oxford University Press.

Serfarty, V. (2004). Online Diaries: Towards a Structural Approach. Journal of American Studies, 38(3), 457-471. Retrieved from: http://www.jstor.org/stable/27557549

Steyaert, J. \& Gould, N. (1999). Social Services, Social Work, and Information Management: Some European Perspectives. European Journal of Social Work, 2(2), 165-175. doi: $10.1080 / 13691459908413815$

Turkle, S. (1995). Life on the Screen: Identity in the Age of the Internet. New York, NY: Simon \& Schuster.

Webb, S. (2003). Technologies of Care. In E. Harlow and S. Webb (eds.) Information and Communication Technologies in the Welfare Services (pp. 223-236). London: Jessica Kingsley.

White, N. (2006). Blogs and community - launching a new paradigm for online community?. The Knowledge Tree, Australian Flexible Learning Association. Retrieved from: https://www.yumpu.com/en/document/view/17755387/blogs-and-community-the-knowledgetree 
Table 1. Country/Blogs Ranking Sites Linking in Alexa (Uploaded data: 02/03/2017)

\begin{tabular}{|l|c|c|}
\hline Country & Reputation (Sites Linking) in Alexa & Rank \\
\hline Spain & http://israelhergon.com/ & 37 \\
\hline Portugal & http://www.cpihts.com/ & 31 \\
\hline Spain & https://lascuatropiedrasangulares.wordpress.com & 30 \\
\hline Italy & blog.assistentisociali.org & 30 \\
\hline Spain & http://www.belennavarro.es/ & 25 \\
\hline Portugal & http://www.apross.pt/ & 24 \\
\hline Italy & https://www.gengle.it/blog/ & 21 \\
\hline Italy & http://digilander.libero.it/ugo.albano/ & 16,5 \\
\hline Spain & http://nosoyasistenta.com/ & 16 \\
\hline Spain & http://www.ehquidad.org/es/blog & 13 \\
\hline Spain & http://lasonrisavacia.blogspot.com.es/ & 12 \\
\hline Portugal & http://www.eas.pt/ & 12 \\
\hline France & https://tremintin.com & 11 \\
\hline France & https://secretpro.fr & 11 \\
\hline Spain & http://espacioservisoci.blogspot.com.es/ & 10 \\
\hline Spain & http://tribulacioneschino.blogspot.com.es/ & 10 \\
\hline France & https://rezo-travail-social.com & 10 \\
\hline Italy & http://socialnet.it/blog/ & 7 \\
\hline France & Dubasque.org & 3 \\
\hline France & http://dases-supap-fsu.over-blog.com/ & 3 \\
\hline Italy & https://assistentesocialeprivato.it/blog & 2 \\
\hline Italy & https://saperesociale.com & 2 \\
\hline France & pep80.over-blog.com & 1 \\
\hline Portugal & http://servicosocial.pt/ & 0 \\
\hline
\end{tabular}

Source: Self-elaboration. 
Table 2. Country/Blogs Global Rank Alexa

(Uploaded data: 02/03/2017)

\begin{tabular}{|l|c|r|}
\hline Country & Global Rank in Alexa & Rank \\
\hline Italy & blog.assistentisociali.org & $1,279,750$ \\
\hline Italy & https://www.gengle.it/blog/ & $1,391,629$ \\
\hline Portugal & http://www.eas.pt/ & $1,496,483$ \\
\hline Spain & http://nosoyasistenta.com/ & $1,640,902$ \\
\hline Spain & http://www.trabajo-social.es/ & $1,773,332$ \\
\hline France & https://secretpro.fr & $2,066,409$ \\
\hline Portugal & http://www.cpihts.com/ & $3,124,773$ \\
\hline France & https://tremintin.com & $3,228,136$ \\
\hline Spain & http://todotrabajosocial.org/ & $3,494,007$ \\
\hline Spain & https://inmaculadasol.com/ & $3,553,168$ \\
\hline France & Dubasque.org & $4,194,161$ \\
\hline Portugal & http://www.apross.pt/ & $4,201,599$ \\
\hline Portugal & http://servicosocial.pt/ & $4,271,895$ \\
\hline France & http://dases-supap-fsu.over-blog.com/ & $5,018,372$ \\
\hline Spain & http://www.belennavarro.es/ & $7,458,358$ \\
\hline Spain & https://lascuatropiedrasangulares.wordpress.com & $7,517,542$ \\
\hline Spain & http://israelhergon.com/ & $7,587,629$ \\
\hline Italy & https://assistentesocialeprivato.it/blog & $8,278,264$ \\
\hline France & pep80.over-blog.com & $8,403,544$ \\
\hline Italy & https://saperesociale.com & $10,763,864$ \\
\hline France & https://rezo-travail-social.com & $14,721,649$ \\
\hline
\end{tabular}

Source: Self-elaboration. 
Table 3. Variations in ranking by country, based on Majestic indicators

(Uploaded data: 02/03/2017 
Table 4. External impact of the blog, according to Alexa \& Majestic

(Number of external links which lead to a blog)

\begin{tabular}{|c|c|c|c|c|c|}
\hline \multicolumn{3}{|c|}{ Impacto externo del blog en Alexa } & \multicolumn{3}{|c|}{ Impacto externo del blog en Majestic } \\
\hline Country & Reputation (Sites Linking) in Alexa & Rank & Country & Backlinks in Majestic & Backlinks \\
\hline Spain & http://israelhergon.com/ & 37 & France & https://rezo-travail-social.com & 93696 \\
\hline Portugal & http://www.cpihts.com/ & 31 & France & https://secretpro.fr & 3595 \\
\hline Spain & https://lascuatropiedrasangulares.wordpress.com & 30 & Portugal & http://www.eas.pt/ & 969 \\
\hline Italy & blog.assistentisociali.org & 30 & Italy & http://digilander.libero.it/ugo.albano/ & 933 \\
\hline Spain & http://www.belennavarro.es/ & 25 & Portugal & http://www.apross.pt/ & 396 \\
\hline Portugal & http://www.apross.pt/ & 24 & Spain & http://israelhergon.com/ & 278 \\
\hline Italy & https://www.gengle.it/blog/ & 21 & France & https://tremintin.com & 212 \\
\hline Italy & http://digilander.libero.it/ugo.albano/ & 16,5 & Spain & http://www.belennavarro.es/ & 190 \\
\hline Spain & http://nosoyasistenta.com/ & 16 & Spain & http://nosoyasistenta.com/ & 171 \\
\hline Spain & http://www.ehquidad.org/es/blog & 13 & Italy & blog.assistentisociali.org & 148 \\
\hline Spain & http://lasonrisavacia.blogspot.com.es/ & 12 & Spain & http://lasonrisavacia.blogspot.com.es/ & 77 \\
\hline Portugal & http://www.eas.pt/ & 12 & Spain & http://tribulacioneschino.blogspot.com.es/ & 71 \\
\hline France & https://remintin.com & 11 & France & http://dases-supap-fsu.over-blog.com/ & 47 \\
\hline France & https://secretpro.fr & 11 & Portugal & http://www.cpihts.com/ & 30 \\
\hline Spain & http://espacioservisoci.blogspot.com.es/ & 10 & Italy & https://assistentesocialeprivato.it/blog & 2 \\
\hline Spain & http://tribulacioneschino.blogspot.com.es/ & 10 & Italy & https://saperesociale.com & 2 \\
\hline France & https://rezo-travail-social.com & 10 & Portugal & http://servicosocial.pt/ & 2 \\
\hline Italy & http://socialnet.it/blog/ & 7 & Italy & http://socialnet.it/blog/ & 1 \\
\hline France & Dubasque.org & 3 & & & \\
\hline France & http://dases-supap-fsu.over-blog.com/ & 3 & & & \\
\hline Italy & https://assistentesocialeprivato.it/blog & 2 & & & \\
\hline Italy & https://saperesociale.com & 2 & & & \\
\hline France & pep80.over-blog.com & 1 & & & \\
\hline
\end{tabular}

Source: Self-elaboration. 


\section{Table 5. External impact of the best positioned 50 blogs in Majestic} (Backlinks in Majestic)

\begin{tabular}{|c|c|c|}
\hline Country & URL/Domain & Backlinks \\
\hline France & Rezo-travail-social.com & 93696 \\
\hline Italy & http://www.artigianosociale.com/ & 30999 \\
\hline Italy & Lenius.it & 15018 \\
\hline Spain & https://mariajoseaguilaridanez.wordpress.com/ & 5534 \\
\hline France & Secretpro.fr & 3595 \\
\hline Portugal & http://www.eas.pt/ & 969 \\
\hline Italy & http://digilander.libero.it/ugo.albano/ & 933 \\
\hline Spain & https://lascuatropiedrasangulares.wordpress.com & 669 \\
\hline Portugal & http://www.apross.pt/ & 396 \\
\hline Spain & http://israelhergon.com/ & 278 \\
\hline France & Tremintin.com & 212 \\
\hline Spain & http://www.belennavarro.es/ & 190 \\
\hline Spain & http://nosoyasistenta.com/ & 171 \\
\hline Italy & blog.assistentisociali.org & 148 \\
\hline Spain & http://trabajosocialdospuntocero.blogspot.com.es & 139 \\
\hline Spain & http://www.trabajo-social.com/ & 136 \\
\hline Spain & http://lasonrisavacia.blogspot.com.es/ & 77 \\
\hline Spain & http://tribulacioneschino.blogspot.com.es/ & 71 \\
\hline Spain & http://trabajosocialpenitenciario.blogspot.com.es/ & 55 \\
\hline France & http://dases-supap-fsu.over-blog.com/ & 47 \\
\hline Spain & http://raizmandragora.blogspot.com.es/ & 45 \\
\hline Spain & http://espacioservisoci.blogspot.com.es/ & 45 \\
\hline Portugal & http://www.cpihts.com/ & 30 \\
\hline Italy & blog.assistentisociali.org & 25 \\
\hline Spain & http://pasionporeltrabajosocial.com/ & 24 \\
\hline Spain & http://www.trabajo-social.es/ & 18 \\
\hline Spain & https://emprenderentrabajosocial.wordpress.com/ & 18 \\
\hline Spain & http://trabajosocialmq.blogspot.com.es/ & 17 \\
\hline Spain & http://pablodelarosa.blogspot.com.es/ & 15 \\
\hline Spain & http://www.rociocdamas.com/ & 14 \\
\hline Spain & http://vademecumsocial.blogspot.com.es/ & 9 \\
\hline Italy & luigibadolati.blogspot.com & 6 \\
\hline Spain & ttps://tiempodetrabajosocial.wordpress.com/ & 6 \\
\hline Spain & https://trabajosocialcorporativo.com/ & 5 \\
\hline Spain & http://thinkingonsocialwork.weebly.com/blog & 5 \\
\hline Spain & http://www.peritajesocialmadrid.com/ & 4 \\
\hline Italy & https://assistentesocialeprivato.it/ & 2 \\
\hline Italy & https://saperesociale.com & 2 \\
\hline Portugal & http://servicosocial.pt/ & 2 \\
\hline Spain & https://socialvirtualwork.wordpress.com/ & 2 \\
\hline Spain & http://www.ehquidad.org/es/blog & 2 \\
\hline Spain & http://itrabajosocial.com/ & 2 \\
\hline Spain & https://rtsocial.wordpress.com/ & 2 \\
\hline
\end{tabular}

Source: Self-elaboration. 
Table 6. Alexa \& Majestic blog listing with major impact on external links

\begin{tabular}{|c|c|c|c|c|c|}
\hline Country & Alexa & Rank & Country & Majestic & Rank \\
\hline Spain & http://israelhergon.com/ & 37 & France & Rezo-travail-social.com & 93696 \\
\hline Portugal & http://www.cpihts.com/ & 31 & Italy & http://www.artigianosociale.com/ & 30999 \\
\hline Spain & $\begin{array}{l}\text { https://lascuatropiedrasangulares.wordpres } \\
\text { s.com }\end{array}$ & 30 & Italy & Lenius.it & 15018 \\
\hline Italy & blog.assistentisociali.org & 30 & Spain & $\begin{array}{l}\text { https://mariajoseaguilaridanez.wordpress.c } \\
\text { om/ }\end{array}$ & 5534 \\
\hline Spain & http://www.belennavarro.es/ & 25 & France & Secretpro.fr & 3595 \\
\hline Portugal & http://www.apross.pt/ & 24 & Portugal & http://www.eas.pt/ & 969 \\
\hline Italy & https://www.gengle.it/blog/ & 21 & Italy & http://digilander.libero.it/ugo.albano/ & 933 \\
\hline Italy & http://digilander.libero.it/ugo.albano/ & 16,5 & Spain & $\begin{array}{l}\text { https://lascuatropiedrasangulares.wordpres } \\
\text { s.com }\end{array}$ & 669 \\
\hline Spain & http://nosoyasistenta.com/ & 16 & Portugal & http://www.apross.pt/ & 396 \\
\hline Spain & http://www.ehquidad.org/es/blog & 13 & Spain & http://israelhergon.com/ & 278 \\
\hline Spain & http://lasonrisavacia.blogspot.com.es/ & 12 & France & Tremintin.com & 212 \\
\hline Portugal & http://www.eas.pt/ & 12 & Spain & http://www.belennavarro.es/ & 190 \\
\hline France & https://tremintin.com & 11 & Spain & http://nosoyasistenta.com/ & 171 \\
\hline France & https://secretpro.fr & 11 & Italy & blog.assistentisociali.org & 148 \\
\hline Spain & http://espacioservisoci.blogspot.com.es/ & 10 & Spain & $\begin{array}{l}\text { http://trabajosocialdospuntocero.blogspot. } \\
\text { com.es }\end{array}$ & 139 \\
\hline Spain & http://tribulacioneschino.blogspot.com.es/ & 10 & Spain & http://www.trabajo-social.com/ & 136 \\
\hline France & https://rezo-travail-social.com & 10 & Spain & http://lasonrisavacia.blogspot.com.es/ & 77 \\
\hline Italy & http://socialnet.it/blog/ & 7 & Spain & http://tribulacioneschino.blogspot.com.es/ & 71 \\
\hline France & Dubasque.org & 3 & Spain & $\begin{array}{l}\text { http://trabajosocialpenitenciario.blogspot.c } \\
\text { om.es/ }\end{array}$ & 55 \\
\hline France & http://dases-supap-fsu.over-blog.com/ & 3 & France & http://dases-supap-fsu.over-blog.com/ & 47 \\
\hline Italy & https://assistentesocialeprivato.it/blog & 2 & Spain & http://raizmandragora.blogspot.com.es/ & 45 \\
\hline Italy & https://saperesociale.com & 2 & Spain & http://espacioservisoci.blogspot.com.es/ & 45 \\
\hline France & pep80.over-blog.com & 1 & Portugal & http://www.cpihts.com/ & 30 \\
\hline Portugal & http://servicosocial.pt/ & 0 & Italy & blog.assistentisociali.org & 25 \\
\hline
\end{tabular}

Source: Self-elaboration. 